CATALAN REVIEW

Catalan Review

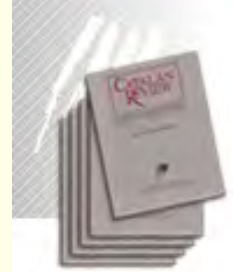

You are accessing the Digital Archive of the Catalan Review Journal.

By accessing and/or using this Digital Archive, you accept and agree to abide by the Terms and Conditions of Use available at http://www.nacs-

catalanstudies.org/catalan review.html

Catalan Review is the premier international scholarly journal devoted to all aspects of Catalan culture. By Catalan culture is understood all manifestations of intellectual and artistic life produced in the Catalan language or in the geographical areas where Catalan is spoken. Catalan Review has been in publication since 1986 .
NORTH

AMERICAN

CATALAN

SOCIETY
Esteu accedint a l'Arxiu Digital del Catalan Review

A l' accedir i / o utilitzar aquest Arxiu Digital, vostè accepta i es compromet a complir els termes i condicions d'ús disponibles a http://www.nacs-

catalanstudies.org/catalan review.html

Catalan Review és la primera revista internacional dedicada a tots els aspectes de la cultura catalana. Per la cultura catalana s'entén totes les manifestacions de la vida intel lectual i artística produïda en llengua catalana o en les zones geogràfiques on es parla català. Catalan Review es publica des de 1986.

\title{
Breaking the Social Contract: EI Comte Arnau, Violence, and Production in the Catalan Mountains at the Turn of the Century Dorothy Noyes
}

Catalan Review, Vol. XIV, number 1-2, (2000), p. 129-158 


\section{BREAKING T'HE SOCIAL CONTRACT: EL COMTE ARNAU, VIOLENCE, AND PRODUCTION IN THE CATALAN MOUNTAINS AT THE TURN OF THE CENTURY ${ }^{1}$}

\section{DOROTHY NOYES}

On January $8^{\text {th }}$, 1900, the composer and musicologist Felip Pedrell writes a letter to the leading modernista poet of Catalonia, Joan Maragall, urging him to create a poem about Count Arnau, "aquella leyenda que es más que una leyenda, una verdadera teogonía de raza, un estallido de fuerzas naturales que han engendrado, quizá, todo nuestro folk-lore" (that legend which is more than a legend, a genuine racial theogony, an explosion of natural forces which have engendered, perhaps, all of our folklore; Pedrell quoted in Terry, 26). ${ }^{2}$

By a coincidence neither man can fail to find significant, the first part of Maragall's long narrative poem on Count Arnau has that very day been published in the magazine Catalonia. Maragall writes that the poem will feature in his next volume, on Catalan legendary figures as they can be understood today, entitled Visions. "Me bice la ilusión de que dentro de estas Visions, de su conjunto, se podria encontrar algo de las madres del alma catalana y de su evolución." [I dared to hope that inside these Visions, in their ensemble, one could meet something of the mothers of the Catalan soul and of its evolution; Terry 27.]

This legend of Count Arnau is, on the face of it, an unlikely candidate for the germ engendering all of Catalan tradition and the Catalan national soul, much less to be associated with the Mothers whom Goethe defined as the deepest source of all creative inspiration. ${ }^{3}$

I I publish this essay with reluctance, both as an autodidact in Catalan literature and as not yet having had the opportunity to review the documentation with any degree of thoroughness. But I hope that the suggestions made here will be of interest to readers better qualified than I to evaluate them. Versions of this work have been presented at the First Draft Group of the Department of English at the Ohio State University (1999), the Annual Meeting of the American Folklore Society (1999), and the colloquium at Indiana. University from which this special issue is drawn: my thanks to all those audiences for helpful comments and especially to Josep Miquel Sobrer for his generous and meticulous assistance.

2 Maragall's correspondence with Pedrell was conducted in Castilian. Most of the citations in Catalan in this article antedate Fabra's standardization of the literary language: I have retained the original orthography, use of italics, and punctuation. Note that ellipses in all citations are not cuts I have made in the text, but a punctuation device of the authors.

3 In Faust Part II, Act 1 (75-80). 
It is the story of a nobleman damned to wander through eternity for feudal abuses, apparently ill according with an emerging nation aspiring to define itself by its modernity in relation to the rest of Spain. Nonetheless, Pedrell and Maragall immediately embarked on a Wagnerian operatic setting of the legend, and they were hardly alone: the story has inspired at least fifty literary settings and as many in music, as well as, in recent years, comic books and even a television miniseries. ${ }^{4}$ It has indeed become the core myth of the Catalan nation.

We may find a key to the power of the story in Pedrell's metaphor of violent birth: the explosion of natural forces." Catalonia at the turn of the century was undergoing a rapid industrialization entailing both radical transformation of its mountain landscape and a restructuring of traditional class relations marked by intense repression on one side and recurrent violent explosion on the other. In searching for a viable form of social contract which would stabilize the region for orderly development, the new industrial bourgeoisie turned to two models: Catalonia's feudal past and the patriarchal farmstead of its rural present, grounded in the pact of matrimony. The story of Count Arnau presents and problematizes both of these models, and bourgeois literati use it in two ways. In representations designed for the general public, they reshape oral tradition to model working-class acquiescence to an unequal contract. In representations for their own consumption, they obsessively rehearse scenes of rupture, attempting to resolve the paradox of making promises they intend to break from the outset. In turn, the scanty evidence we have for the oral narratives of Count Arnau suggests that a new mountain proletariat increasingly integrated into international workers' movements is perfectly conscious of the dangers of making a pact with the devil.

Let us begin with what the literati defined as their raw material: a ballad collected in the Pyrenees in 1843 by the early folklorist Marià Aguiló:

-Tota sola feu la vetlla, muller [lleial? tota sola feu la vetlla, viudeta igual?

No la faig jo tota sola, comte l'Aman no la faig jo tota sola, valga'm, Déu, [val!

-Qui tenin per companyia, muller [lleial?

-Déu i la Verge Maria, comte [l'Arnau.
-Are you watching all alone, loyal [wife?

Are you watching all alone, little [widow?

-I am not all alone, Count Arnau,

I am not all alone, God help me!

[ensuing repetitions eliminated]

-Who do you have for company, [loyal wife?

—God and the Virgin Mary, Count [Arnau.

4. See Camps and Soldevila 1994 for an anthology, bibliography, and overview. Romeu Figueres 1948 is the classic study of the Arnau song and legend. 
- A on ne tenin les vostres filles, Imuller lleial?

- A la cambra són que broden, comte ll'Arnau.

A la cambra són que broden seda $i$ [estam.

-Me les deixarien veure, muller [lleial?

- Massa les espantarieu, comte [l'Arnau.

$-A$ on ne teniu les criades, muller [lleial?

-A la cuina són que renten, comte Il'Arnau.

- A on ne teniu els mossos, muller Illeial?

-An el llit són que reposen, comte [l'Amau.

- Paguen-los bé la soldada, muller [lleial.

-Tan prest com l'bauran guanyada, [comte l'Arnau.

- Per on beu entrat vos ara, comte Il'Arnau?

- Per la finestra enreixada, muller [lleial.

-Ail que me l'baurien cremada, [comte l'Arnau.

-Solament no l'be tocada, muller [lleial.

-Què és això que us ix per la boca, [comte l'Arnau?

-Males paraules que be dites, muller [lleial.

-Què és això que us ix pels ulls, [comte l'Amau? - Males mirades que be dades, [muller lleial.

-Què és això que us ix per les [aurelles, comte l'Amau?
-Where do you keep your [daughters, loyal wife? -They're in the chamber embroi[dering, Count Arnau. They're in the chamber embroide[ring silk and linen.

-Would you let me see them, loyal [wife? -You'd frighten them too much, [Count Arnau.

-Where do you keep the servant [girls, loyal wife? - They're in the kitchen washing, [Count Arnau.

-Where do you keep the servant [lads, loyal wife? - They're in bed resting, Count [Arnau.

-Pay them their wages well, loyal [wife. - Just as soon as they've earned [them, Count Arnau.

- How did you get in here, Count [Arnau? -Through the grated window, [loyal wife.

-Ai! you must have burned it, [Count Arnau. -I haven't even touched it, loyal [wife.

-What is that coming out of your [mouth, Count Arnau? -Bad words I spoke, loyal wife.

-What is that coming out of your [eyes, Count Arnau? -Bad looks I gave, loyal wife.

-What is that coming out of your [ears, Count Arnau? 
-Són llames de foc que em cremen, [muller lleial.

-Què és això que us surt per les [mans, comte l'Arnau?

- Les coses mal manejades, muller [lleial.

-Què és això que us surt pels peus, [comte l'Aman?

- Els mals passos que donava, muller [lleial.

-Què és això que bi ba en l'entrada, lcomte l'Arnau? -És el cavall que m'espera, muller [lleial.

- Baixeu-li grana i civada, comte [l'Arnau.

-No menja gra ni civada, muller [lleial, sinó ànimes condemnades, viudeta [igual.

-Quina bora és, que el gall ja canta, [muller lleial?

- Les dotze hores són tocades, comte [l'Arnau.

- Vos dic que no em feu l'oferta, [muller lleial, que com més em feu l'oferta, més Ipena em dau.

- Perquè sou condemnat ara, comte li'Amau? - Per soldades mal pagades, muller [lleial.

- Ara per la despedida, muller lleial, ara per la despedida, dem-nos les [mans.

- Massa me les cremarieu, comte [l'Arnau, Massa me les cremarieu, valga'm [Déu, val!
- They're flames of fire that burn [me, loyal wife.

-What is that coming out of your hhands, Count Arnau? -The things badly handled, loyal [wife.

-What is that coming out of your [feet, Count Arnau? -The bad steps I took, loyal wife.

-What is that in the courtyard, [Count Arnau? -It's the horse waiting for me, loyal [wife,

-Take grain and oats down to it, [Count Arnau. -It doesn't eat grain and oats, loyal [wife, but condemned souls, little widow.

- What is the hour, that the cock is [crowing, loyal wife? -Midnight has sounded, Count [Arnau.

-I tell you not to make offerings for me, loyal wife,for the more you make offerings for me, the more suffering [you give me.

-Why are you condemned now, [Count Arnau? -For wages badly paid, loyal wife.

-Now in farewell, loyal wife, now in farewell, let's take hands.

-You'd burn them too much, [Count Arnau, You'd burn them too much, God [support me! 
In this text, we see the social world not of a medieval castle but of a contemporary farmstead. A strong opposition is drawn between a woman who fulfills all of her contractual obligations - marital fidelity, supervision of her daughters and household, prayers for the dead, prompt compensation to her servants - and a man who apparently has fulfilled none of his, for the range of his torments suggests an equally wide range of misdeeds. There is a suggestion of sexual transgression in the Count's entry through the window -in Catalan folksong almost always an anticipation of an illicit encounter-and possibly in the wife's refusal to let him see his daughters. But the specific sin that damns him is his failure to pay his workers, and this is the only sin that is explicitly defined in the ballad.5

Within a few years of the ballad's publication in 1843 , Catalan romantic writers turn the Count into a figure out of Victor Hugo. Forgotten is the mundane detail of the unpaid servants. His sins are now of a more grandiose nature: blasphemies, pacts with the devil, intensive abuse of the jus primae noctis, and more spectacular adulteries, notably the forced entry of the convent of Sant Amanç, whence he abducts the abbess, and seduces her, rapes her, or violates her corpse, according to the author's predilection. He is, however, a patriot, and commits heroic carnage against the Moors. Provincial scholars of the period attempt to identify the count with documented historical figures, linking him to their own mountain region.

In the same period, an oral legendary of the count is emerging in the region of the Alt Ripollès and Alt Berguedà - not the high mountain still isolated from the city, but the upper valleys of the rivers flowing into Barcelona, rivers up which industrialization is rapidly moving. The poet-priest Jacint Verdaguer, himself a child of a rural artisanal family, collected several Arnau stories in Gombreny on a summer excursion in 1878. Sex is conspicuous by its absence in these fragmentary legends. Rather, the count is turning from a landowner to a developer. He diverts rivers to have irrigation for his fields; he builds staircases in the mountains, and churches and castles on impossibly difficult sites, killing many workers in the process. The devil assists him in these otherwise impossible construction projects, and he is associated with wolves, strange lights, and violent storms as well as with fissures and gaps in the landscape. As in the song, with its questions and responses, the Arnau legends (like other mountain legends of feudal lords collected by Verdaguer) often depict him

5 It's worth noting that the unpaid salaries-now accompanied with giving bad weight ("mesures mal rasades") and all kinds of deception ("deu mil enganys") figure even more strongly in a version collected from oral tradition as late as ro92 (Camps and Soldevila, $92-3$ ). 
responding improperly to a question or failing to keep a promise: he breaks off both contracts and dialogues (Verdaguer 1992:392-404).

By 1878 , a new economic system was beginning to take shape in these river valleys, which already had a long textile and metallurgical tradition. Barcelona industrialists were moving their mills upriver, in search of cheap water power and a placid workforce. As the factories multiplied, rivers were diverted and industrial canals were dug; mining developed in the mountains beyond the towns. The younger children of the farms and the landless laborers evolved into a new mountain proletariat. $^{6}$

Rather than building in the established towns, the manufacturers turned land along the rivers into "industrial colonies," self-contained communities of production comparable to North American company towns. The colony's walls enclosed the factory, worker housing, a school, a store, a public garden, and the two pillars of authority: a church and the country house of the manufacturer. Inside the colony, both men and women worked in the factory, the women for a lower wage. The children went to school to learn religion, the alphabet, and sewing until their early teens, when they too went to work; the young men sometimes continued their education to qualify them for more technical positions in the factory. A patch of garden supplemented the family wage, the company store provided their staples, and the priest and sisters supervised their morals. The gates were locked at night, and periodicals coming in and out were examined for political content. As Enric Prat de la Riba, the ideologue of Catalan nationalism at the turn of the century, observed in his Ley juridica de la industria, the colony was a system of near-total control, physical, economic, and ideological:

En la Colonia Industrial puede rodearse a los obreros de un medio completamente distinto, de un medio sano...se trata de un núclea de población que va a formarse ante los ojos del director o del dueño.

In the Industrial Colony the workers can be surrounded with a completely separate environment, a healthy environment...it is a nucleus of population which forms itself before the eyes of the director or master. (Prat de la Riba 1898, quoted in Serra and Viladés 1987, p.34, and Terradas 1979, 30)

Fearful of unionizing efforts in Barcelona, Catalan industrialists identified a strong patriarchal structure as the safeguard of prosperity, exemplified in the traditional peasant stem-family household as well as

6 An overview and synthesis of the scholarship on the colonies may be found in Serra 2000. Ignasi Terradas (1979) is the strongest proponent of the thesis that the colony system had more to do with the so-called "pau social" (social peace) than with energy sources, and Serra adds to the evidence for this. 
in the church. The owner-master replaced the father figure of the casa pairal, and in extreme cases was spoken of almost as the Lord's anointed: the priest-biographer of Eusebi Güell wrote of the Colonia Güell, "Arreu transpira l'amor de l'obrer al patró, convertit en pare veritable del seu obrer, i encarnació visible de la seva providència en aquest món" (All over [the colony] breathes the love of the worker for the owner, converted into the true father of his worker, and visible incarnation of his providence in this world; quoted in Terradas, 13). Such "patriarchs" would regenerate and transform the "vitiated" souls of the workers (Prat 1898, quoted in Serra 2000, 49-50). Like the authority figures, institutions were conflated in the colony model: a jurist in Igor equates household, church, state, and factory:

[The house is not] una asociación transitoria, sinó una iglesia con culto permanente, un Estado con autoridad inmutable, un centro de producción constante [The house is not] a transitory association, but a church with permanent worship, a State with immutable authority, a center of perpetual production (Santamaria Tous quoted in Roigé 1989, p.3r)

Prat found the earliest model for the industrial colony in the Roman villa:

Convertido al cristianismo el señor de la villa, levantose inmediatamente al lado del pretorium el templo de Jesucristo; cada dominium tuvo su iglesia y su pastor; el bautizo dignificó a los esclavos; el matrimonio indisoluble destruyó la promiscuidad...Algo muy parecido ba de efectuarse hoy.

When the lord of the villa was converted to Christianity, the temple of Jesus Christ was immediately erected next to the pretorium; each dominium had its church and its pastor; baptism dignified the slaves; indissoluble matrimony destroyed promiscuity...Something very similar must be put in effect today. (Prat de la Riba, quoted in Terradas, 29)

But the colony system was more commonly traced to the Middle Ages, the period of Catalonia's independence and greatness. The new manufacturing system was known both to its detractors and to its proponents as "industrial feudalism." The architecture of the colonies bore out the metaphor. The colony walls were often turreted with lookouts, "as if to keep out the Moors," workers used to observe.7 The church was in Romanesque or Gothic style to lend the authority of tradition to its messages, and the house of the owner was called a torre, or tower: often it was an outright castle, with ramparts and crenellations. Such constructions were frequently by far the most

7. This evaluation appears to be traditional and coeval with the colony system: I heard it in 1989 from the child of one of the colonies in the upper Llobregat valley, and it is documented from a Manresan union periodical in 1871 of the early Colonia Sedó (Terradas p.6). 
imposing of their districts, amid crumbling small towns and scattered masies (Serra 2000, 43-44). The symbolism was not lost on the workers, who referred to the torre more directly as a castell or palau (Ferrer, Pinero, and Serra 1997:146) and tore down the colony walls with the collectivizations of the rg3os. The Second Spanish Republic denounced all remnants of traditional authority as "feudalism," and worker songs in the colonies show a clear sense of exploitation:

Aquí dalt de la montanya bi ha uns [cuants fabricants Que no se com se diuen perque no'n [vuy contá tants, Ells dels filats son amos també dels [teixidors, Que ab l'esquena dels pobres ells [vihuen com senyors.
Here up on the mountain there are [some manufacturers

Whose names I don't know because I [don't want to recount so many The mill owners are bosses of the [weavers too

Who live like lords on the backs of [the poor.

"Coplas dels Obrers de Montaña," probably from the 1890 strike, cited in Serra and Viladés, 138

Indeed, "the profits of the Llobregat factories went to build the Eixample" (Josep Noguera i Canal, personal communication, 1989; cf. Serra 2000:20-22): the money went downriver to fund the new bourgeois quarter of Barcelona, full of the medievalizing architecture of Antoni Gaudí and his contemporaries. Gaudís patron and the dedicatee of Prat's essay on the industrial colonies, Eusebi Güell, had factories in the heart of Count Arnau country, and Güell and other colony owners became Counts themselves at the turn of the century, ennobled by Alfonso the Twelfth for their services to Spanish industry. ${ }^{8}$

Into these mountains now thoroughly transformed by canals, mills, quarries, and mines came the folklorist Rossend Serra i Pagès, "preguntant pel Comte l'Arnau" (asking for Count Arnau). In a 1904 essay of that name, he describes a tense fieldwork experience. The peasants don't understand what he wants, and are silent from mistrust or shame; the girls in particular insist they don't remember.

8 Luís Olano, owner of the mines of Figols, became Comte de Figols during the 1908 royal visit of Alfonso XII to the factories of the Llobregat. Alfonso Sala, a textile manufacturer, rejected the title of Marquis in 1908, later accepting one as count. Eusebi Güell was ennobled in 1910. Altogether, 52 titles were granted to Catalans and $\$ 48$ in Spain as a whole between 1872 and 1932 , one strategy by which the Restoration regime integrated its elites and lent the legitimacy of tradition to the modernizers of the state (McDonogh p.110-112). 
$Y$ ja no dich rès dels xicots, que com se passen la tarda de les festes a la vila, ja estan contaminats d'aquella pseudo-civilisació que fa tan fastich; ban vist toros, "D. Juan Tenorio", han sentit couplets en el cafe y fins confegexen periòdichs redemptors del poble. No fan cas del perfum de la terra que'ls du'l ventitjol al fregarse per les ubagues y van a buscar el tuf de lo de for a, ja sigui en la discussió politica tinguda en una taberna, ahont l'ayguardent emmetzina'l cós y la teoria sociologica incompresa perverteix l'ànima, ja en la sala de ball d'ambient irrespirable, escola lasciva y cau de rabons, als acorts d'un piano de maneta, espurnejats per paraulades que ofenen més el sentit comú que la moral, y axò que són indecentes a tot serbo.

And I won't even talk about the young men, who, since they spend their afternoons off in the towns, are already contaminated with that pseudocivilization which is so disgusting; they've seen bullfights and "Don Juan Tenorio," they've heard cabaret songs in the café and they even concoct periodicals to redeem the town. They pay no attention to the perfumes of the earth that the breeze brings them when it brushes the mountainsides, and they go looking for the reek from outside, whether in political discussion in a tavern, where brandy poisons the body and misunderstood sociological theory perverts the soul, now in the asphyxiating air of the dance hall, lascivious school and cave of murmurings, to the chords of a mechanical piano, sparked by speeches that offend common sense more than they do moralsand those are indecent enough. (II)

Here Serra pauses for breath and goes on to say that those people who are willing to talk are so often deficient in expression that their contribution is useless.

Eventually he finds an old man near Montgrony who guardedly admits to some knowledge, but clams up until he is given a cigar. His subsequent testimony is not exactly what the folklorist hoped for:

- El Comte l'Arnau...sí...diuen, ppero jo no m'bo som cregut may!...sí...perque per mi, tot axò són falomies...

- Es clar, peró tant se val; la qüestió és saber lo que la gent ne diu.

-Uuuuy! Si n'arriben a dir y a dir...-

Nova pausa; la curiositat m'anava en aument y la impaciencia també.

-Donchs, com deya...el Comte l'Arnau...però fa mólts anys d'axò...jsìn fa d'anys i panys...; Era en temps dels moros y ell era general...si... $y$ d'en tocom els treya...jpron qu'bo dèu baver trobat a l'bistoria vostè axò!

$-\mathrm{No}$, no bo be llegit enlloch.

- Donses, si vol, ja l'acompanyaré prou a una casa que tenen una historia que bo diu prou;,...sí.

- L'bistoria del Comte l'Aman?

- Què hi sé jo! Es una bistoria que parla dels moros.

- Jo lo que vuy saber es lo del Comte l'Arnau. ¿Què n’beu sentit dir d'axò dels moros?

- Ja li som pron dit...sí...que'ls va fer recular...iy que'n devia fer una estesa! Diu que may més se varen atansar per aquí.

$-Y$ què més? 
- Com un hom es tan burro...no les sab les coses.

-Perồ m'beu dit que lo que's deya del Comte l'Arnau vós no bo creyèu. Qu'es lo que no creyèu?

- Tantes coses! ... Que sortía tot abrandat de foch...

- Veyam, contèumbo axò.

- Sí, es ben senzill...que sortia...com li diré jo... ben abrandat de foch...

- ¿Ahont?

- Per en tocom.

-Y ara no surt?

-Que jo sàpiga, no.-

$Y$ per dirme qu'havia sigut general, qu'havia tret als moros d'en tocom, que sortia ben abrandat de foch per en tocom, qu'havia fet pacte amb el dimoni, qu'era molt dolent, que se'n entrava en el convent de les monges de Sant Amant y que va sortir a la seva viuda, sense afegir ni'l més petit detall, va entretenirme tres bores, ab l'uuuuy! y'l si, fentme saber a cada pas qu'era mólt burro y que tot axò no s'bo creya.

- Count Arnau...yes..they say-but I've never believed it!...yes...because for me all this is just stories...

-Of course, but it doesn't make any difference; the question is to know what people say about him.

-Uuuuy! They say plenty....-

Another pause; my curiosity was rising and my impatience also.

- So, as I was saying...Count Arnau...but that was years ago...years and years!...It was in the time of the Moors and he was a general...yes...and he threw them out of someplace...you must have found that in the history books! -No, I haven't read it anywhere.

-Then, if you like, I'd be glad to take you to a house where they have a history that tells it all;...yes...

- The history of Count Arnau?

-What do I know? It's a history that talks about the Moors.

-What I want to know about is Count Arnau. What have you heard about this with the Moors?

-I've been telling you...yes..that he drove them back - and it must have been a long way! They say that they never set foot here again.

-And what else?

-Well, since one is so stupid - one doesn't know things-

-But you told me that you didn't believe the things they said about Count Arnau. What didn't you believe?

- So many things!...That he used to come out all aflame with fire. ..

- Let's see, tell me about it.

-Yes, it's very simple...that he came out...how can I explain it...all aflame with fire...

-Where?

- Someplace.

-And he doesn't come out nowadays?

- Not that I know of.

And to tell me that he'd been a general, that he'd thrown the Moors out of someplace, that he used to come out all aflame with fire someplace, that he'd made a pact with devil, that he was very bad, that he entered the convent of 
Sant Amant and that he appeared to his widow, without adding the least detail, he kept me for three hours, with his uuuuy! and his yes, explaining to me at every step that he was very stupid and that he didn't believe any of it. (12-13)

This informant is notably eager to avoid committing himself, and distances himself by every possible means from the stories: declaring his disbelief, referring Serra to the authority of written history, and placing the events in the far past of the Moorish occupation. His double generic evaluation of the stories as falornies (tales not to be credited) and as història is particularly interesting: he is clearly aware of the extensive fabrication of Arnau narratives by the local literati. Certainly the fragments he offers relating to the Moors and the convent were not found in Verdaguer's oral accounts and suggest a literate origin.

At the next encounter, mediated by "una persona que tenia prou valiment sobre d'ell perque no pogués negarse a contestarme lo que li preguntés" (a person who had enough favor over him that he could not refuse to answer what I asked him, I3) Serra asks the heir to a casa pairal, "Qu'beu sentit dir del Comte l'Arnau?" [What have you heard about Count Arnau?, 13] The young man stops smiling. "Nothing!" Serra gives him a cigar and begins to feed him lines: haven't you heard he appears to his widow? don't you know the song of the damned soul? The young man insists he pays no attention and doesn't believe any of it. Neither do I, Serra reassures him, at which the young man is further bewildered. Serra explains that he only wants to preserve the tradition, that customs and beliefs, like the house and the land, keep a family going.

The man relaxes, repeats that he believes none of it, and at Serra's next question about Arnau's dogs says, "I've heard them myself." At sunset, he goes on, he's heard Arnau whistle as he calls his dogs. One night he heard him pass under the earth, a big rumble. Where was he going? asks Serra. His father used to tell him; he doesn't remember.

An old man from Gisclareny holds Serra for an hour, as the hopeful scholar plies him with cigars.

Per $f i$, tot arrencant-se maquinalment un repeló de l'ungla, ' $m$ va dir enrabonant enforfollat i després de pensarsbi mólt:

- El Comte l'Amau volia fer eixir el Llobregat a Sant Joan de Mataplana y com el gall va cantar massa aviat, el riu no va arribarbi; $y$ ara surt per les cingleres de sota Castellar d'en Huch.

At last, mechanically pulling a hangnail, he told me, mumbling and after thinking for a long time:

- Count Arnau wanted to make the Llobregat river come out at Sant Joan de Mataplana, and since the cock crowed too soon, the river didn't make it, and now it comes out by the cliffs of Castellar de N'Hug, ( 16$)$ 
Then he clams up again. Serra asks his name and he changes color and asks,

-No dech pas haver fet cap mal jo, dientli axò?

-No, bome, nó, al contrari

- Es que com un hom no sab de lletra...

-No tinguèu por; us demano'l nom per saber d'abont be tret axò.

- Es que jo poré ser pobre, però de mal, no'm som pas volgut fer may a dingú.

"Have I done anything wrong, telling you this?"

"No, man, no; to the contrary."

"You see, when you don't know your letters-"

"Don't be frightened; I'm only asking your name to know where I got this from."

"It's just that I may be poor, but as for wrong, I've never wanted to do ill to anyone," (I6)

Serra reassures him and gives him some money, and the man goes away, still protesting that he wishes ill to no one and didn't say it out of malice. Serra adds that the tradition about deviating the source of the Llobregat is "mólt arrelada" (deeply rooted) in the region. It may, however, be worth recalling that the soon-to-be count Güell was at that very moment deviating the Llobregat a few kilometers south of its source at the cliffs of Castellar de N'Hug in order to build a cement factory, which opened in 1904, the year Serra's essay was published.

Next Serra finds a tenant farmer who used to take sheep along the plain of Sant Amant, near the ruins of the convent supposedly assaulted by Arnau. "Did you hear whether Arnau used to appear around there?" asks Serra. The masover is noncommittal at first: he recalls being frightened, perhaps they said it was Arnau, he didn't remember. But soon he recalls in detail striking features of the convent ruins:

De rochs de riu, era; sent aixis que per aquells encontorns tot es pedra calcinar. Prou qu'bo deyen els pagesos: iqu'n devia costar de moneda fer aquell convent ab els rochs duts de tan lluny!

[The wall] was of river rocks; while around here everything is limestone. The peasants said it often enough: what must it have cost in money to make that convent with stone brought from so far away!(17)

Now Serra asks him about the ring of iron, and the man himself volunteers that this is where Arnau tied up his horse, still to be seen near the rosebush remaining from the nuns' garden. Serra suggests skeptically that there are rosebushes all over, but the man objects that this was a cultivated rosebush with double blossoms, not the wild shepherds' roses, and that its thick dry trunk was proof of its age. And 
he confirms Serra's question about a tunnel for the Count to pass, adding that it had to go under the river, as Arnau could not pass through blessed water. Although here at last is oral testimony supporting the literate accounts of Arnau's sexual adventures, the informant is more interested in "matter out of place" (Douglas 1966): these exotic stones and flowers, with the exercise of wealth and power that their presence implies, and Arnau himself, as a presence who cannot move normally in the mountains and has to do violence to them.

Serra clearly suffers in these agonizing encounters from not "knowing how to ask," as contemporary ethnographers would put it (Briggs 1986). His informants are not unreasonably suspicious of this well-dressed stranger's intentions, and the old man from Gisclareny is afraid that the single story he provides will be interpreted as malicious, harmless though it might seem to recount that a figure of legend failed in a construction project.

Standing back, we can understand why no one was eager to talk about Arnau to a member of the bourgeoisie. Count Arnau had become a Restoration industrialist in fancy dress. Folklorists sought popular confirmation of the stature and power of a figure more important to their own class than to the people on whom his legitimacy rested. The people, indeed, were moving on to new models of the social order. The workers' movements which had contributed to fifteen years of general strikes and anarchist bombings in Barcelona had clearly made their way upriver along with industrialization: the periodicals and sociology of the young workers in the taverns attest to this. The legends of Count Arnau, insofar as they are popular at all, 9 appear to belong to a more general European folklore of seigneurial abuses now being developed, through socialist and anarchist discourses of "feudalism," into critiques of emergent class relations under industrial capitalism. Such a conflation was especially easy in semiperipheral regions of Europe where the old hierarchies were far

9 This is a real question, pending a thorough reexamination of the documentation by a skeptical eye. It's not impossible that a very minor folk phenomenon was seized and developed by collectors at the very moment of documentation and synthesis into something of greater significance, and it is quite clear that the scholarship fed upon itself in subsequently construing Arnau as a major theme and figure of Catalan folklore. Josep Romeu i Figueras, the great philologist who wrote his dissertation on Arnau in the first dark years of the Franco regime (1948), later made a remarkable admission about his fieldwork in Arnau country in 1943-44: "El comte Amau no és conegut a les nostres terres enquestades per via tradicional, sino per informació llibresca o en tot cas per fama d'origen forà. Mai no sorti a relluir espontaniament per part dels informants, sinó a causa de les meves pregantes, $i$, en tal cas, les respostes foren vagues $i$ confusos els records" (Count Arnau is not known through tradition in the territories surveyed, but through information from books or in any case through a fame of external origin. The topic never emerged spontaneously from the informants, but only as a result of my questions, and in such cases the responses were vague and the memories confused. 2000:27). 
from dead. Catalonia, of course, had little hereditary nobility left after 1714, but the Spanish king's need to legitimize industrialists by ennoblement marked the semiperipheral status of Spain as a whole, notorious for its Ungleichzeitigkeit with the rest of Europe-it was a country living under several dispensations at once, uncannily noncontemporaneous with itself.10 The folk demonization of the count - again to be equated with such European figures as Faust, Don Juan, the Wandering Jew, Peer Gynt, and the vampire-responds both to this sense of uncanniness and to a more religious sense that divinely sanctioned relations in both the social and the natural worlds were being perverted (cf. Taussig I980).

This religious critique was taken up by Jacint Verdaguer when he returned to the story of Arnau in 1901, after a protracted and painful encounter with the new industrial nobility. As a young poet in the early 1870 s he had been taken up by the bourgeoisie as the poet of the Catalan folk, who would bring the songs of the mountains to Barcelona and construct a national literature from them. To be freed of parish duties, he was eventually taken to live in the palace of the newly ennobled Marquis of Comillas, the richest merchant-financier in Spain. ${ }^{11}$ There, as well as confessor to the family, he served as almoner, distributor of the charity by which inequality in Spain had been justified for centuries.

In the late $188 \mathrm{os}$, Verdaguer became increasingly concerned about the misery of the urban working class, which he witnessed through the lines of petitioners to the palace of the Marquis, and at the same time involved with a sectarian movement practising exorcisms. He became convinced that the devil was actively poisoning social relations, hardening the hearts of elites, whose neglect of Christian charity was driving the poor, in their despair, to embrace the evils of anarchism. Relations with the second Marquis and his family became increasingly tense as he filled his corner of the palace with petitioners and spent increasingly large sums in donations, reaching breaking point when Verdaguer urged an exorcism on the childless Marquesa, and exhorted her to become an angel of charity instead of living in the world. Deep in debt and cast out of the palace with the connivance of his bishop, the poet became increasingly embittered and combative, spending

1o See Moretti's discussion, $4 \mathrm{I}^{-}-42$, following Ernst Bloch; as well as, for Spain, James W. Fernandez's discussion of dispensations (1990).

II Like most of the wealthiest pre-1898 commercial bourgeoisie of Catalonia, Antonio López, the Marquis of Comillas, made his first forture in Cuba, and his shipping empire had its origins in the slave trade (Lahuerta 1993, 19-20). While his class spoke of feudalism, then, it had direct ties to a less paternalist exercise of power in the near past. For the Comillas family and its links to the industrialist Güells, see Lahuerta 1993, 7-65 and passim. 
much of the violent years of the I8gos impoverished and under ecclesiastical censure, suspended as a priest, and ferociously attacking both Marquis and bishop in the liberal press as betrayers of the poor. Ill health and exhaustion led him to submit to the bishop in 1900, with the subsequent restoration of his privileges and rehabilitation as the national poet, but the Marquis never spoke to him again. ${ }^{12}$

In I90I the poet published his last book, Aires del Montseny [reezes of the Montseny], containing a poem on Count Arnau for the first time in his voluminous poetic output. ${ }^{13}$ Several lyrics are addressed directly or indirectly to the bishop and the Marquis, himself now suffering the economic aftermath of the Spanish defeat of 1898 . Despite their surface submission, the poems constitute a fierce critique of both men, and the book read as a whole sets out to define the proper national relations between mountain and city, between nature and labor, and between the church, the people, and their secular leaders. The poems conflate the church, maternity, the pure air of the mountains, the songs of the folk, and the Virgin Mary through reminiscences of the poet's own mother and descriptions of Marian mountain sanctuaries. In one poem, the Virgin is addressed as Comtessa - countess.

Arnau is not the only Count appearing in the collection: many of the poems invoke James the First, the count of Barcelona who, through submission to the Virgin, was enabled to conquer Mallorca and Valencia for Christianity and turn Catalonia into a great nation. Arnau follows the other path, and indeed the whole volume is structured by disjunctions, with repeated references to right and wrong roads, right and wrong guides.

The poem builds on ballad structures in its parallelisms and use of dialogue and refrains, making them still more schematically binary for didactic purposes. The Count's sin begins with an act of defiance against his wife's guidance: as he is going out, she urges him to saddle the white horse, not the black one. He insists that the black horse will take him on the rough roads he prefers, and saddles it, "baldament fos Satanàs" [ven if it were the devil himself; 1949, 689]. She blesses him as he leaves, but it is too late. His good angel "el guiaria a l'esglésiali ell a la vila fa caplon hi ha nines que perdreli pobres per escanyar" [would guide him to the church/ and he heads towards the town/ where there are girls to wrong/ and poor people to squeeze dry; 689-690]. "Pobres

12 For the biography of Verdaguer and this episode in particular, 1 have drawn on Verdaguer 1994, Arbó 1970, Garolera 1996, and the volumes of Verdaguer's correspondence.

13 Note that Verdaguer's Canigó is an epic of the nation's founding, and if Arnau were really so central a figure he might have been expected to make an appearance in it. 
per escanyar" recalls the folk expression escanyapobres (literally, a poor-strangler), for a usurer. Verdaguer often used this expression for the Marquis in his years of combat, and it is worth noting that he never blamed the Marchioness: the count and the countess of this poem are clearly associated in his mind with the Comillas family.

Arnau belongs to the devil by the time he has finished with the town: he returns to the mountains and is pursued by wolves and thunderstorms, true to the oral legends. $\mathrm{He}$ has lost control of his horse: he is frightened and would return if he could, but the horse is Satan and will make him follow the bad road forever.

Verdaguer's Arnau poem and his book as a whole may be understood as blaming the Catalan elite for ten years of extraordinary social violence. The poet proposes a conservative solution, neither the revolution sought by working-class leaders, nor rampant capitalism, but a genuine industrial feudalism, in which those placed by God in high positions would be mindful of their responsibilities; would demand obedience, but themselves obey a higher law. ${ }^{24}$ His book responds also to Joan Maragall's Visions $i$ Cants, published a year earlier in 1900 , in which a very different analysis is made.

Maragall was a poet of the next generation, which spoke not of national Renaixença but of Modemisme, and came from the new bourgeois class - indeed, he had written an enthusiastic review of Prat de la Riba's Ley juridica de la industria (1960 v.2, 543-544). Visions $i$ Cants takes several protagonists of Catalan legend and transforms them into Nietszchean supermen, creative destroyers whose violent energies clear the ground for the construction of a new nation. His Joan Serrallonga, a bandit of ballad and folk drama, is portrayed making a deathbed confession, describing each sin with so much relish in recollection that the priest is justifiably skeptical of his sincerity; but he renounces each in order to gain more life, and dies declaring, "Crec en la resurrecció de la carn" [I believe in the resurrection of the flesh]. Maragall's Arnau, as he seduces the Abbess, blasphemes against his wooden rival, the crucified Christ, demanding of the beautiful nun: "com és que ara malparles de la vida, / per la que estàs tan fortament armada?" [how can you denounce life, when you are so strongly armed for it?, 29].

The "veus de la terra" [voices of the land] ask Arnau what more he can desire, and he asks in turn for the immortality of each of the

I4 To be sure, the Marquis himself avowed allegiance to this project: he was one of the Catalan industrialists most active in promoting the social Catholicism of Leo XIII's $189 \mathrm{r}$ encyclical Rerum novarum. Using the resources of his shipping company, he organized an 1894 pilgrimage of workers and owners to Rome, in which many of the industrial colonies participated (Terradas, 157). 
elements, then refuses each insofar as it lacks the full sentience and agency of human life. At last the earth grants him all the immortalities together:

Seràs roure, seràs penya, seràs mar esvalotat, seràs aire que s'inflama, seràs astre rutilant.

Seràs home sobre bome, perquè en tens la voluntat. (32-33)
You'll be an oak, you'll be a cliff,

You'll be a stormy sea,

You'll be flaming air,

You'll be a shining star,

You'll be a man above men,

because you have the will.

"Seras home sobre bome," the superman. He leaves the pregnant abbess, now too much tied to the earth, declaring, "Jo sóc sols dels meus braços $i$ els meus passos" [I belong only to my own arms and my own footsteps, 1974,35$]$.

As Maragall begins to collaborate with Pedrell on an Arnau music drama, which they define in Wagnerian fashion not as an opera but as a Fiesta de Arte Patrio [Festival of Art of the Fatherland], Arnau revisits him and he finds the vitalist Nietszchean solution too simple. Now Arnau is weary of so much autonomy: he longs for redemption and reincorporation into human community, not just the elements. The second part of Maragall's poem has Arnau listening horrified to the song of his wife, hearing himself damned. "Aquesta cançó tan negra, qui la podrà enblanquir? "How can we whiten the song? he asks (45).

Love can whiten it, says his wife: not Arnau's for her but her love for him. She proceeds with a series of metaphors recalling the industrial move upriver. Arnau is dried up, with no love to give, and her love for him is only a trickle, having been so often diverted and wasted, but there is still a font viva, a living spring, and its flow can restore him, and cleanse the dust from his mal cami [bad road] - just as the waters of the.Llobregat and the T'er washed off and assumed the pollutions of industrialization. Now the wife spins and sings, and the flow of her singing begins to change the song, bringing him peace and sending him heavenward. "Canta, esposa, fila I canta, /que el patî em faràs suau!l Quan l'esposa fila $i$ canta,/ el casal s'adorm en pau-" [Sing, wife, spin and sing,/for you make my suffering light!/ When the wife sings and spins, the household sleeps in peace, 46]..$^{\text {I5 }}$ Arnau cannot look to his wife to effect his salvation unassisted, however, and

I5 Note how different this is from the folksong, in which-and this is one of the most stable motifs of the song as collected over the years - the prayers of the virtuous wife intensify the torments of the guilty husband. 
she indeed must look to him. He holds a series of dialogues with his daughters and his unpaid servants, and all of their souls are now bound up with his: his redemption matters not only to him but to all of them, in a vision of unavoidable mutual involvement: "Tots salvats, perduts amb tu:/ o ets tothom o no ets ningu" [All are saved or lost with you/you're either everyone or no one, so]. Here Maragall revisits the organic social model he celebrated in his enthusiastic review of Prat de la Riba's Ley juridica de la industria in 1898 , but now he highlights the central responsibility of the father figure (Maragall 1960 v.2, 544$)^{16}{ }^{16}$

The move towards collective redemption is disrupted by Adalaisa, the abbess seduced by Arnau after his violent entry into her sanctuary and abandoned when she becomes pregnant. Dying in despair at the end of part I, Adalaisa is now, like Arnau, a specter. But she has become a more fervent convert to vitalism than Arnau himself, and she wants life, not redemption: she wants to bear her child, and mocks the sterility of Arnau's legitimate daughters. She is vehement enough to break frame and address the poet, asking him what real life is like: he responds with a sentimental tribute to marriage and family, which she ferociously rejects, declaring

Ab! Tingués jo els ulls oberts a llum [del dia, d'altre crit, d'altre modo ploraria.

El xiscle esgarrifós de la partera, com de bèstia ferida, em fóra grat;

$i$ el fill que duc per vies tan estranyes,

sortiria ensagnat de mes entranyes,

i jo riuria amb riure com d'orat.

Què em faria el dolor, ni què, el

ni tot el temps passat de sacrifici, Idesfici, ni les congoixes, ni el perill de mort, si de la vida me trobés com centre,

$i$ sentís com l'infant, desprès del [ventre, morat d'ofec encara, arrenca el plor! (5s)
Ah! If I could open my eyes to the [light of day, I'd cry with another shout, another [manner. The terrifying screech of the birthing [woman, like that of a wounded beast, I'd [welcome; and the son I carry by such strange [passages would come out bloody from my [guts,
and I would laugh like a madman. What would I care for pain, or [anxiety, or all the time passed in sacrifice, or the anguish, or the risk of death, if I could find myself like the center [of life, and feel the infant, after the belly, still spotted and gasping, break out in [a cry! 
She continues,

Tu em tens per morta $i$ jo em tinc per [viva; mes tal com si enterrada viva fos, tinc el voler de mos sentits furios, perquè bi ba alguna cosa que me'l [priva. Si no me la pots traure de damunt, de què us val, doncs, poetes, la $(55-56)$
You call me dead and I hold myself [alive; but as if I had been buried alive, I have the furious desire of my senses, for something is depriving me of [them. If you can't pull it off of me, what good then, poets, is your [poetry?

The poet can only plead with her that "la poesia tot just ha començat, / $i$ és plena de virtuts inconegudes" [poetry has only just begun,/and is full of unknown powers, 56]. Like the earth, it is an undeveloped resource.

The Wagnerian redemption of the sinner by the self-sacrifice of his victims is thus overturned when one of the victims demands her own freedom. ${ }^{17}$ The choice of the nun for this role must be read in the context of a period when both working class and progressive bourgeoisie used the convent as a metaphor for the old regime, which walled up precious resources in musty enclosures, leaving them to decay and the population to starve. The count who rapes nuns in the Arnau literature is echoed in radical rhetoric, most famously in Alejandro Lerroux' 1906 exhortation to his "Young Barbarians," urging them to attack the convents, "lift up the veils of the novices, and elevate them to the category of mothers" (quoted in Mitchell 1998, 61). Here Maragall makes Adalaisa herself consent, in part justifying Arnau's violence, but with a disquieting suggestion that the victim may become in turn the aggressor.

This, of course, is what happened historically, when a working class deprived of participation in the political process or collective bargaining rights turned to violence as its only

means of voicing grievances. Maragall, unlike most members of his class, could see regenerative potential in working-class violence as well as in that of Arnau. A poem written after the bombing of the Barcelona opera house takes the patriarchal model and declares its inevitable Oedipal reversal:

17 The well-known passionate Wagnerism of the Catalan bourgeoisie is a theme I cannot take up here in detail, but Wagner's exploration of central tensions of modernity in medieval dress is generally acknowledged as a key influence on Modernisme; and the theme of redemption clearly had special resonance in this period. 


\section{Paternal}

(Tornant del Liceu en la nit del 7 de novembre, 1893 )

Furient va esclatant l'odi per la terra, regalen sang les coll-torçades testes, i cal ana' a les festes amb pit ben esforçat, com a la guerra.

A cada esclat mortal - la gent trèmula es gira: la crudeltat que avanca,-la por que [s'enretira, se van partint el món...

Mirant el fill que mama, -la mare el pare arruga el front.

[que sospira,

Pro l'infant innocent, que deixa, satisfet, la buidada [mamella, se mira an ell, $\rightarrow$ se mira an ella, i riu bàrbarament.

(1960, p.90)
(Returning from the Liceu on the night of 7 November, 1893)

Raging hate goes exploding over the [land, neck-twisted heads are spouting [blood, and one has to go to celebrations with an effortful breast, as if to war.

With every mortal explosion-the [tremulous people turn: the cruelty which advances, - the fear [which draws back, are dividing the world between [them... Watching the son who suckles, - the the father wrinkles his brow.

[mother who sighs,

But the innocent babe, which leaves off, satisfied, the looks at him,-looks at her, [emptied breast, and laughs barbarously.

A less ferocious but similarly disconcerting finish is applied to one of Maragall's "narracions líriques," an undated prose piece called "Cercant el Comte l'Arnau" [In Search of Count Arnau]. ${ }^{18}$ The poet describes visiting the convent of Sant Joan de les Abadeses while summering in the area. As he looks at the crumbling cloister, used as an army barracks during the last Carlist war and more recently as a pig sty, he attempts to think a thousand years back, picturing Arnau's irruption into the space of the nuns. As does Serra i Pagès, Maragall recalls the Arnau story in order to comment on the transformation of life in the mountains. He is disgusted by the town agutzil, who tells him matter-of-factly of the recent history of the cloister and smiles, superior to such "falomies," at the poet's question about Arnau lore,

18 Other articles of this genre are dated between 1904 and 1907; the piece certainly belongs to this period, when Maragall was continuing to rework the Arnau theme, and is thus roughly contemporary with Serra's account.

19 The word here is Maragall's. We do not know if it was the agutzil's also, but note the similarity with Serra's informants in the same period. 
observing that the one old man who knew such things is dead and now they are over and done with. The poet observes, "d'ença que hi va el tren $i$ bi ha una fabrica, es va tornant com un raval de Barcelona" [since the train and the factory arrived, it's turning like a suburb of Barcelona, 1960: I, 704]. Maragall is even more offended by a young man who boasts of his scholastic prowess, comparing his own achievements to the slow progress of Agustí, a fourteen-year old beneit [simpleton] who follows the poet around and is the real focus of the article. Agustí addresses the poet eagerly as "senyor," is delighted to receive coins from him, and is in general as respectful and affectionate as any theorist of paternalism could desire. Maragall in turn has a tenderness for this dirty child, whose body is already bent from his work of gathering fodder for his mother's rabbits, and looks to him for reassurance on Arnau:

- ¿Oi que no, Agusti, que no s'ba acabat tot aixó...?

$I$ ell, dòcil, s'engresca $i$ crida amb cantarella ferèstega:

-No....se...nyor!

No sé com bo va dir que cap endins dels seus ulls esgarriats bi vaig veure una reculada de segles espantosa.

(1960: I, 705)
-It's not all over, all that, is it, Agusti?

And he, docile, gets excited and shouts in savage singsong:

-No-sir-ree!

I don't know what it was about the way he said it that made me see, in the depths of his wandering eyes, a terrifying recoil of the centuries.

While Maragall is appalled by the "aire de superioritat" of the new mountain class and has to content himself with the continuity of the old social order in someone locally dismissed as the village idiot, even that old order - embodied in the Arnau story as well as in Agustí- is ambiguous to him. This beneit, at once docile and untamed, is something more complex than, say, Wordsworth's Idiot Boy, and what is described as ancient in him echoes the newborn savagery of the urban child in "Paternal."

After the Tragic Week of 1909 , when convents are sacked and churches burned in a revolt spurred by the calling-up of army reservists, Maragall's fear of popular violence is overcome by his recognition of its transformative power: ${ }^{10}$ He writes of experiencing the mass as if for the first time in the ruins of a burned church:

20. The jouralist Gaziel dismisses the common perception of Maragall as a conservative votary of order, and anticipates my argument here: just as Goethe carried Mephistopheles at his elbow, Maragall was always followed by the shadow of the Count. Poet of the bourgeoisie par excellence, Maragall was aesthetically a ".purc anarchist," and Gaziel sees both bourgeois Modernisme and Catalanist politics as 
Entreu, entreu, la porta és ben oberta: vosaltres mateixos vos la beu oberta amb el foc i el ferro de l'odi...Destruint la iglésia beu restaurat la Iglésia, perquè aquesta és la veritable, aquesta és la viva, aquesta és la que es fundà per a vosaltres, els pobres, els oprimits, els desesperats, els odiadors...I com ara la vèieu tancada, enriquida per dintre, emparada pels rics $i$ els poderosos i els que bi venien a adormir el sen cor en la pau de les tenebres, vosaltres, amb la vostra pobresa, i la vostra rebel-lió i la vostra desesperació $i$ el vostre odi $n^{\prime}$ beu envestit la porta, $i$ en els murs tan ferms beu obert la bretxa, i os la beu reconquistada. Enter, enter, the door is wide open: you yourselves have opened it with the fire and iron of hatred...Destroying the church you have restored the Church, because this is the true one, this the living one, this the one founded for you, the poor, the oppressed, the desperate, the haters... And since you saw it closed, enriched on the inside, sheltered by the rich and the powerful and those who came to put their hearts to sleep in the peace of its darkness, you, with your poverty and your rebellion and your desperation and your hate have broken down the door, and in those strong walls you have opened a breach, and you have reconquered it for yourselves. (1960, v.I, 777)

Here the church is reborn in the violence which opens up sterile enclosures - the same violence Adalaisa welcomes if it will bring new life.

But Maragall's collaborator, Pedrell, like the Count himself, wants to whiten the song. His goal is to create a work for the entire public: their correspondence deals at length with the problem of finding an adequate stage for this Fiesta de Arte Patrio. "How shall we make it reach the soul of an entire people," writes Pedrell; "how shall we return to them what has come out of them?" (Terry, 40). This indeed was the mission of most literary and musical treatments of the story: to return the story to the people and get them to tell it differently. Seeking a popular language of legitimation, the bourgeoisie attempted to appropriate and direct the cultural work of the mountaineers as they had their material labor: As we saw from the field excursions, these efforts were already active in the mountains. For a Barcelona audience, Pedrell sought to stabilize the Count's redemption and to clarify the message. Adalaisa's protests were excised from the text. Pedrell writes to Maragall in 1904: "La sintesis de ese Festival se balla asi, trocada dos palabras, el pueblo por la esposa y el hilar por el trabajar $o$ ó rezar en los tres versos en que termina la moraleja" [The synthesis of this Festival is found in this, with two words exchanged: the people instead of the wife, and for spinning, working or praying, in the three lines which conclude the moral]:

Canta, oh poble, prega $i$ canta.

Quan el poble canta i resa

el casal sadorm en pau.

(5o)
Sing, oh people, pray and sing. When the people sing and pray, the household sleeps in peace. 
The patriarchal vision is explicitly turned to the industrial context: the singing, spinning, praying wife is replaced with singing, spinning, praying textile workers. Pedrell's vision thus supports Adorno's account of bourgeois opera's "costume quality," presenting real social relations in elaborate feudal dress for the seduction of a mass audience (1994).

The Fiesta de Arte Patrio was never realized in Barcelona, owing to a mix of financial and logistical difficulties (Terry $22-23$ and passim). Pedrell hoped to hold the performance in the monumental surround of the Arenas of Barcelona, which would have the added advantage of displacing the Spanish bulls in favor of a Catalan hero at a key site of popular diversions. Unfortunately, as Pedrell bitterly observes, prevailing economic and political conditions had already effected the reverse substitution (Terry, 5I). Lluís Millet, director of the Orfeo Català, and Maragall himself were apparently in favor of the Greek theater then being built as the omphalos of the Park Güell, Güell and Gaudi's attempt to realize the spirit of Catalonia in landscape architecture (cf. Lahuerta 1993, 144-172). Güell himself is not to known to have taken an active interest in the project, perhaps because he had already seen his vision of industrial integration brought to life in an 1892 opera with a less ambiguous story. "Garraf," by Ramon Picó i Campamar (libretto) and Josep García Robles (music) personifies the landscape of one of Güell's properties south of Barcelona, and depicts the angel Labor liberating the Dona d'Aygua - a Catalan water nymph - from her underground prison. In this period Güell was working hard to build an aqueduct that would exploit the underground springs of the Garraf to bring drinking water to Barcelona. Garraf, the personification of the land and father of the Dona d'Aygua, is dried up from the death of his wife-we may associate him with Amfortas, Parsifal being Güell's favorite Wagner opera. ${ }^{2 I}$ Anticipating Maragall's second Arnau poem, women, water, and work are once more bound up in the redemption of men. More generally, in what Lahuerta calls the "symbolic production" of Eusebi Güell (176), the wife and the workers are aligned in a fashion that anticipates both Pedrell and Verdaguer. Several representations of St. Elizabeth of Hungary, the patron of Güell's wife Isabel, ${ }^{22}$ appear in

sharing deep presuppositions with the working-class anarchism of the same period regarding the performative power of violent gestures (1960, rool). Gaziel's association of Arnau with anarchist violence rather than the Middle Ages is quite clear.

21 I summarize from the much fuller discussion of Eahuerta 1993,176-221, who relates the content of the opera to the paternalist social-Catholic industrial vision of Güell as later embodied in Gaudís architecture for the Colònia Güell.

22 Sister, incidentally, to Claudi López, the second Marquis of Comillas. 
Gaudís Palau Güell: a mosaic depicts her spinning and awaiting her husband, and a mural shows her giving charity to the poor. The salon of the Palau was also the site for the performances of Garraf, given to such chosen guests as the nuncio of Leo XIII rather than to the general public imagined by Pedrell. To be sure, song had its place for Güell's workers, and a hymn composed by the Garraf poet and Güell's daughter for the choir of the Colònia Güell sang of labor the redeemer and conqueror of discord (185). Perhaps to tell the Arnau story to a large public in an open space was to stir up discord once more.

Although Barcelona proved a problematic site for performing Arnau to the working class-or indeed to the bourgeoisie-, the mountain folk were mobilized as performers of the legend themselves during the same period through an act of elite reframing. The festa major of any mountain town at the turn of the century featured a local dance to enable courtship and competitive display under the supervising eyes of the community. ${ }^{23}$ In the Alt Ripollès and Alt Berguedà a set of related dances - the Gala de Campdevànol, the Dansa de Gombreny, and the Dansa de Falgars - entailed the making of couples through the agency of a capdanser, a senior male, by the waving of a flowered staff or another symbolic object over the head of the young woman before handing her to the young man, often after dancing with her himself. In this period, local literati began to explain this pattern as a reminiscence of the feudal dret de cuixa, and the senior male was often directly associated with the abusive Count. Such accounts were provided in festival programs and other media reaching both locals (workers, manufacturers, and the farming and commercial population in between) and the summer visitors; they persist as the standard origin narratives of the dances today. ${ }^{24}$ In this way, both local participants and elite spectators were taught to understand the dances as a performance of acknowledgment and submission. Just as the literary narrations known to Serra's informants placed words in the mouths of the folk and urged them to repeat the changed text as

23 To be sure, as we have scen from Serra i Pagès's complaints, such dances already found it hard to compete with the new dances and music arriving from the cities. In more isolated villages, priestly authority could often effectively suppress "balls moderns" (Verdaguer 1992, 212), and nontraditional dances were an arena of constant struggle and prohibitions in the industrial colonies, where it was not Figaro but the Count or his priest who called the tune (Terradas 1979, 165).

${ }_{24}$ Precise dares and references cannot be easily established here, and much archival work remains to be done. Pujol and Amades give the theory as part of the conventional wisdom (1936, 266); Capmany refers to it skeptically (1948, 76). More recently, Camps and Soldevila briefly $(1994,31)$ and Francàs in greater detail $(1997,68-72)$ give complex and unfortunately unfootnoted summaries of an extensive early $20^{\text {th }}$ century scholarship arguing the presence of feudal and in some cases specifically Arnaldian reminiscences in this group of dances of the Alt Ripollès and Alt Berguedà. 
their own, the insertion of Arnau into popular dances forced a show of acquiescence on the bodies of participants, attempting the literal incorporation of ideology.

In this period when cultural hegemony based in paternalist Catalanism offered the best hope against a counter balance to to workers' movements, and cultural initiatives were proliferating in the industrial colonies in particular (Terradas 1979, p.165), Arnau was not the only story told of industrial feudalism. In the same region, another legend was revived. A restructuring of the same story of abuse and redemption, it splits the feudal lord into his positive and negative aspects, and averts the virgin sacrifice. The story of Galceran de Pinós and the Hundred Damsels derives from a fifteenth-century literary legend of aristocratic provenance, created as a justification of the remaining seigneurial privileges in a period when these were being challenged. In the late igth century, it became the subject of nearly as much elaboration as the story of Arnau. The son of the lord of Bagà, Galceran, is captured by the King of Granada, who demands a ransom of a hundred cows, a hundred sheep, and so on, as well as a hundred damsels. Galceran's horrified parents repeatedly refuse to send the girls to this "fate worse than death," but their vassals come to them and say,

"Señor, es tanto el agradecimiento que os tenemos por los constantes beneficios que nos habéis otorgado, considerándonos más bien como á bijos que como vasallos sujetos á vuestro servicio, que queremos demostrároslo auxiliándoos en el terrible trance en que estáis colocado. No consideréis imposible reunir el rescate que pide por vuestro bijo y señor nuestro, el rey de Granada: procurad reunir todo lo necesario, y en cuanto á las doncellas, que el bárbaro reclama, nosotros las proporcionaremos sacándolas de nuestras corazones y de nuestra propia sangre."

Lord, our gratitude to you is so great for the constant benefits you have granted us, considering ourselves rather your children than vassals subject to your service, that we wish to demonstrate it by helping you in this terrible moment of peril. Do not believe it is impossible to gather the ransom asked for your son and our lord by the King of Granada: gather all that is necessary, and, as regards the maidens demanded by the barbarian, we will provide them, casting them out of our hearts and of our very blood."(Vilardaga 1890, 14I)

St. Stephen, the patron of the town, gets them out of this pass by miraculously liberating Galceran, who meets the procession of girls on the road to Granada. In his gratitude, he gives them all dowries and frees all his vassals from the "mals usos" or evil feudal customs, among them the jus primae noctis.

This retelling, from 1890 , puts particular emphasis on the nature of the sacrifice to be required of the young women, and places the 
responsibility for it entirely in the will of the people, which overpowers the generous reluctance of the lord. ${ }^{25}$ The collective happy ending is a product of popular self-sacrifice, and the jus primae noctis is only a threat in the background should the damsels not choose to go willingly.

A seemingly very different genre, the romantic realist novel-la pairal, translates the scene of the jus primae noctis to the patriarchal farmstead of the mountains in the present day. Frequently in these novels, the virtue of a hardworking, religious, beautiful girl is threatened by the desires of a wealthy heir at the same time that her family's property is threatened by the heir's father. A moral conversion to Catalan family values, effected by the patient virtue of the heroine, transforms threatened rape and dispossession into marriage and uniting of the properties-the same result in more consensual, contractual guise. ${ }^{26}$

But Maragall cannot rest with these two options. He rejects the "rhetoric of innocence" of the Hundred Damsels story, the same that allows Faust to distance himself from Mephistopheles (Moretti 22). ${ }^{27}$ The Count is not the devil, not a wandering Jew, not a foreign vampire, not a Moorish invader: both his evil and his creative power are owned as native.

The poet continues to consider the other option of redemption, and for his final Arnau poem in I9II takes his point of departure from Wagner's Flying Dutchman, in which the heroine's singing of a ballad both brings the phantasm into being and, eventually, sends them both back into the world of myth. ${ }^{28}$ In "The End of Count Arnau," the

25 See Riquer $2000,163-243$, for an account of the legend in the late Middle Ages and early modern period. The only element of recent oral tradition he comes up with is a 1914 account of the suicide of three of the damsels before leaving with the others - and if this is hardly violent resistance, neither is it the willing submission proclaimed in the texts (239).

26 For examples of this plot, see Carles Bosch de la Trinxeria, L'beren Noradell (1978 [1889]), and Martí Genís i Aguilar, "La llum blava" (1988 [1904]).

27 Indeed, Maragall notes in another context-though here he associates Mephistopheles with the mocking and cynical rather than the more overtly destructive tendencies of the bourgeoisie- "el Faust catalín se parece ridículo a si mismo muy a menudo, porque lleva a Mefistófeles dentro de si, como una maldición" (the Catalan Fause very often seems ridiculous to himself, because he carries Mephistopheles inside himself, like a curse) (1960 v.2, 649).

28 Although Maragall himself is not known to have drawn the connection between the poem and Wagner's opera, the parallels are extensive. Senta, like Maragall's shepherdess, sings a ballad about a blasphemer and his punishment, and in so doing, becomes obsessed with the protagonist. Grey (2000:78-80) argues convincingly that Wagner represents her as recomposing the song in performance, like a true oral performer, and that this process, as in the case of the shepherdess, is understood as bringing the world of the mythical protagonist into the real world of the performer and breaking open his imprisonment in endless repetition. Moreover, Senta is aligned with a group of spinning women: one might see her song as differing from theirs, an 
count is still wandering, now carrying the burden not of unpaid wages but of "l'amor degut i no pagat" [love owed and not repaid, 1974, 59]. $\mathrm{He}$ also carries the burden of conscious intelligence (and most critics see this as Maragall's own declaration): "ara, mort-viu, haig de fer vialcom un despert entre adormits!" [now, dead-alive, I must make my way/like a man awake among men who sleep, 60].

As he makes his way, he hears the earth crying against him and hears his widow singing-presumably her old responses. Then her voice changes, and he hears another voice blended with it, singing "la cançó antigalamb una nova pietat." [the old song with a new piety, 63].

This is the end of the poem:

Es una ven encara viva.

No ve del cel, ni ve dels llimbs:

ve de la terra, tan festiva, amb verd [als camps i amb sol als cims.

En un pendís de la muntanya bi ha una pastora de l'ull blau que, tot cantant la cançó estranya, se'l va estimant, el comte Arnau.

Un campanar sona en l'altura les gents se mouen pels sembrats;

esquellejant salta i pastura l'escampadissa dels ramats...

\section{I la pastora enamorada} canta que canta la cançó; li ha mudat tota la tonada $i$ ba redimit el pecador. Que des de que ella l'ha cantada amb altra ven, amb altre acord,

ja no bi ba ànima damnada...

La cançó ha mort, la cançó ha mort.

Seguiu el pla, seguiu la serra,

vila i poblat, per on vulgueu; la cançó és fora de la terra i ja mai més la sentireu.
It is a voice still living.

It comes not from heaven, nor from

[below:

it comes from the earth, so festive, with green in the fields and sun on the

On a slope of the mountain [summits. there's a blue-eyed shepherdess who, singing that strange song, goes falling in love with him, Count

A belltower sounds on high;

[Arnau.

the people move across the seeded [fields; the scattering of the flocks jumps and feeds, bells ringing...

And the shepherdess in love sings and sings the song she's changed all the melody and has redeemed the sinner. For since she has sung it with a new voice, with a new [concord, now there is no more damned soul... The song is dead, the song is dead. Follow the plain, follow the [mountain, town and hamlet, wherever you wish: the song is out of the land and never again will you hear it.

anticipation of reunion with their distant sailor lovers, only in the transcendent rather than materialist mode of the longed-for encounter. One would also want to call to mind Maragall's familiarity with Ibsen's Peer Gynt (1867), in which yet another demonic capitalist of rural origins is redeemed at the last by the song of a faithful woman. 
Alguns diran que la sentiren; altres ni en tenen cap record; quins l'oblidaren, quins ni l'oiren...

La cançó ha mort, la cançó ba mort. Jo, d'una vella ja afollada

pel pes dels anys, la vaig sentir.

ja sense to, a glops, trencada... I aquella vella es va morir.

Cantant, cantant nasqué la infamia, $i$ descantant, la redempció:

el comte l'Arnau tenia l'ànima a la mercè d'una cançó.

Lo que la mort tanca i captiva, sols per la vida és deslliurat: basta una noia amb la veu viva per redimir la bumanitat. (63)
Some will say they heard it once, Others don't even remember it; the ones who've forgotten, the ones [who never heard..

The song is dead, the song is dead.

I, from an old woman already [maddened from the weight of years, heard it [once with no tone left, in gulps, broken... And that old woman died.

Singing, singing, infamy was born, and descanting, redemption.

Count Arnau had his soul at the mercy of a song.

What death shuts up and captures, can be delivered by life alone.

A girl with a living voice is enough to redeem humanity.

On one level, we may say that oral tradition itself redeems Count Arnau. The cry of the earth and the widow's lament are transformed into the girl's ballad, which also incorporates the voice of the Count. As she goes "cantant $i$ descantant, "varying the song in performance, a bitter memory becomes a living aesthetic presence, a source of pleasure even to the singer.

But is the song alive at the end? It seems to have sucked the life out of the girl singer, who becomes an old woman and dies off. Maragall's poem celebrates the resilience of oral memory, its flexibility and capacity for reconciliation over time, but he is, as Adalaisa reminds us, engaged in the written word. Folksong, like the mountain landscape, the labor of the people, and the bodies of women, is a generative resource: one which must be freed from its old enclosures and developed but also reified into commodity - not quite dead, but not quite alive either. All these resources require "un despert entre adormits," a "man awake among sleepers," a visionary poet-capitalist, to kill them off and then restore them to this phantom life.

And there is no stability in this new world in which long-term debts replace the everyday reciprocities of the old social pact: redemption must be endlessly and dangerously deferred. "Love owed and not repaid" gives birth, as it soon would in Barcelona, to the "barbarous laugh" of the next generation. 


\section{REFERENCES}

ADORno, Theodor. "Bourgeois Opera." Opera through Other Eyes. Ed. David J. Levin. Stanford: Stanford University Press, 1994. 25-43. ARBO, Sebastiân Juan. La vida trágica de mosén Jacinto Verdaguer. Trans. Joan Fuster. Barcelona: Ed. Planeta, I970.

BOSCH DE LA TRINXeria, Carles. L'hereu Noradell. Barcelona: Edicions 62, 1978.

BRIGGS, Charles. Learning How to Ask: A Sociolinguistic Appraisal of the Role of Language in Social Science Research. Cambridge: Cambridge University Press, 1986.

CAmps, Josep, and Llorenç SoldeviL.A. El Comte Aman (i el Comte Mal). Tres rutes literàries. Argentona: L'Aixernador, 1994.

CAPMANY, Aureli. El ball $i$ la dansa popular a Catalunya. Història, descripció i ensenyament. Barcelona: Editorial Millà, 1948.

Douglas, Mary, Purity and Danger. London: Routledge and Kegan Paul, 1966.

FERNANDEZ, James W. "Enclosures: Boundary Maintenance and Its Representations over Time in Asturian Mountain Villages (Spain)." Culture through Time: Anthropological Approaches. Ed. Emiko Ohnuki-Tierney, Stanford: Stanford University Press, 1990. 94-127.

FERRER, Llorenç, Jordi Piñero, and Rosa Serra. El Llobregat, nervi de Catalunya. Manresa: Angle Editorial, 1997.

Francas I Patsí, Àngel. La Pobla De Lillet. Història, costums i tradicions de la Vall de Lillet (Berguedà). Berga: Columna/Albí, 1997.

GAROLERA, Narcís. Sobre Verdaguer: biografia, literatura, llengua. Barcelona: Ed. Empúries, 1996.

GAZIEL. "Facetas de Juan Maragall." 193I. Joan Maragall, Obres completes. Barcelona: Selecta, 1960. V.2, 998-100I.

Genís I Aguilar, Martí. "La llum blava." Novel.les vigatanes. Barcelona: Curial, 1989. 9-6I.

Goethe, Johann Wolfgang. Faust Part Two. Tr. Philip Wayne. Harmondsworth: Penguin, 1959.

GREY, Thomas. "Romantic Opera as 'Dramatic Ballad': Der Fliegende Holländer and Its Generic Contexts." Richard Wagner. Der Fliegende Holländer. Ed. Thomas Grey. Cambridge Opera Handbooks. Cambridge: Cambridge University Press, 2000. 65-91. LAHUERTA, Juan José. Antoni Gaudi. Madrid: Electa España, 1993.

MARAgal., Joan, Obres completes. Barcelona: Selecta, r960.

- El Comte Arnau. Ed. Joan-Lluís Marfany. Barcelona: Edicions 62, I974.

MCDONOGH, Gary Wray. Good Families of Barcelona: A Social 
History of Power in the Industrial Era. Princeton: Princeton University Press, 1988.

MilÀ I FONTANALS, Manuel. Romancer català. Barcelona: Edicions 62, 1980.

Mrtchell, Timothy. Betrayal of the Innocents: Desire, Power, and the Catholic Church in Spain. Philadelphia: University of Pennsylvania Press, 1998.

MoRETTI, Franco. Modern Epic: The World System from Goethe to García Márquez. Tr. Quintin Hoare. London: Verso, 1996.

PRAT DE LA RIBA, E. Ley jurídica de la industria. Barcelona, i898.

Pujol, Francesc, and Joan Amades. Diccionari de la dansa, dels entremesos, $i$ dels instruments de música $i$ sonadors. Cançoner Popular de Catalunya, Volum I. Dansa. Barcelona, 1936.

RiQUeR, Martí de. Llegendes històriques catalanes. Barcelona: Quaderns Crema, 2000.

ROIGE I VENTURA, Xavier. "Els juristes i la família catalana." L'Avenç December 1989: 28-33.

ROMEU Figueres, José. El mito de 'El Comte Arnau' en la canción popular, la tradición legendaria y la literatura. Barcelona: CSIC/Archivo de Etnografia y Folklore Catalanes, 1948.

ROMEU I FIGUERAS, Josep. Recerques d'etnologia i Folklore. Barcelona: Abadia de Montserrat, 2000.

Serra, Rosa, and Ramon Viladés. La Colònia Pons de Puig-Reig (1875-1987). Berga: Ambit de Recerques del Berguedà, 1987.

SERrA, Rosa. Colònies Tèxtils de Catalunya. Manresa: Angle Editorial, 2000.

Serra y Pagès, Rosend. "Preguntant pel Comte l'Arnau." Alguns escrits. Barcelona: Estampa de la Casa Miquel-Rius, 1926. II-18.

TAussig, Michael. The Devil and Commodity Fetishism in South America. Chapel Hill: University of North Carolina Press, 1980.

TERRADAS, Ignasi. La colònia industrial com a particularisme bistòric: l'Ametlla de Merola. Barcelona: Laia, 1979.

TERRY, Arthur. "L'epistolari de Joan Maragall i Felip Pedrell." Estudis Romànics 7 (1959-60): II-62.

Verdaguer, Jacint. Obres completes. Barcelona: Biblioteca Perenne, 1949.

- Rondalles. Barcelona: Barcino, 1992.

- En Defensa Pròpia. Ed. Lluîsa Plans. Barcelona: La Magrana, 1994.

Vilardaga y Cañellas, Jacinto. Historia De Berga. Barcelona, 1890. 